\title{
CACAT SINTAKSIS KELUARAN WICARA PADA ANAK PENYANDANG AUTIS DI SD LAB PGSD SETIA BUDI DAN SDIT AL-MUBARAK RAWASARI (SUATU KAJIAN NEUROLINGUISTIK)
}

\author{
Oktiani Endarwati
}

\begin{abstract}
ABSTRAK
Penelitian ini bertujuan untuk mengetahui salah satu gangguan bahasa dan komunikasi pada anak autis khususnya konstruksi sintaksis yang diujarkan oleh anak autis. Metode yang digunakan dalam penelitian ini adalah metode deskriptif dengan teknik analisis isi. Penelitian ini dilaksanakan pada semester ke-2 tahun akademik 2013/2014 yaitu pada bulan April-Mei di SD Lab. PGSD, Setia Budi dan SDIT Al-Mubarak, Jakarta. Objek dalam penelitian ini adalah tuturan anak penyandang autis sebanyak 4 orang dan difokuskan pada cacat sintaksis keluaran wicara. Cacat sintaksis keluaran wicara dapat ditandai dengan adanya kesalahan dalam proses produksi bunyi wicara pada tataran alat dan satuan sintaksis. Instrumen penelitian ini adalah peneliti sendiri dibantu dengan gambar-gambar. Berdasarkan analisis data, diperoleh informasi bahwa cacat sintaksis keluaran wicara pada anak autis terjadi pada urutan kata dan frasa. Jumlah kalimat ujaran dalam komunikasi diperoleh sebanyak 67 kalimat ujaran dalam satu konteks ujaran. Hasil cacat alat sintaksis keseluruhan terdiri dari cacat urutan kata berjumlah 17 sebesar 89,47\%; cacat bentuk kata berjumlah 1 sebesar 5,26\%; kesalahan intonasi tidak ditemukan; kesalahan partikel atau kata tugas berjumlah 2 sebesar 5,26\%. Hasil cacat satuan sintaksis keseluruhan terdiri dari kesalahan frasa berjumlah 11 sebesar 73,33\%, kesalahan klausa berjumlah 4 sebesar 26,67\%; dan tidak ada kesalahan dalam tataran kalimat.
\end{abstract}

Kata kunci: Cacat Sintaksis,Anak Autis.

\section{PENDAHULUAN}

Bahasa adalah salah satu aspek penting bagi manusia untuk dapat mengekspresikan diri serta sarana komunikasi dengan lingkungan sekitar. Belajar bahasa pada hakikatnya adalah belajar berpikir, berekspresi, dan berkomunikasi untuk memenuhi berbagai keperluan dalam kehidupan individu ataupun keperluan interaksi sosial dalam komunitas kehidupan di lingkungannya (Sugono, 2012: 2).

Kemampuan unik manusia untuk memperoleh bahasa adalah hasil dari keberfungsian sistem syaraf. Ketidaksempurnaan pada sistem syaraf akan mempengaruhi kemampuan berbahasa seseorang. Gangguan ini sangat kompleks menyangkut bidang kognitif, komunikasi, interaksi sosial, ketertarikan, dan aktivitas imajinasi anak, serta emosional anak.

Anak normal akan memperoleh bahasa secara alamiah tanpa instruksi formal. Biasanya anak normal mulai berbicara pada usia antara 18-28 bulan. Namun, sebagian lainnya karena berbagai sebab mengalami gangguan berbahasa seperti keterlambatan berbicara dan kesulitan dalam memperoleh bahasa serta pembelajaran bahasa.

Pada anak autisme terdapat hambatan dalam kemampuan perkembangan verbal dan interaksi non-verbal. Autisme merupakan salah satu gangguan perkembangan yang umumnya terjadi pada masa kanak-kanak yang ditandai dengan adanya keterlambatan 
dalam beberapa aspek diantaranya keterlambatan atau gangguan dalam berinteraksi sosial, berbicara, dan bahasa. Anak autis berkomunikasi dengan bahasa tubuh dan hanya dapat berkomunikasi secara singkat. Gangguan di bidang komunikasi mencakup gangguan dalam komunikasi verbal maupun non-verbal.

Anak autis menggunakan kata-kata tanpa menghubungkannya dengan arti yang lazim digunakan. Terkadang kata-kata tersebut tidak dapat dimengerti orang lain, tidak menggunakan kata-kata dalam konteks yang sesuai, ekolalia (meniru atau membeo), menirukan kata, kalimat atau lagu tanpa tahu artinya. Tidak semua anak autis mengalami gangguan wicara. Beberapa anak autis dapat berbicara dengan normal dan lancar, sebagian lagi mengalami hambatan dalam berbicara, dan sebagian kecil lainnya tidak berbicara sama sekali atau no speech (Sunu, 2012: 88).

Seperti yang terjadi pada Faiz murid kelas 4 di SD Lab. PGSD Setia Budi ketika diajak berkomunikasi tidak ada kontak mata, berbicara secara singkat cenderung satu kata, tidak mengerti intonasi dan makna pola kalimat yang subjek ujarkan.

$\begin{array}{ll}\mathrm{P} & : \text { Coba Faiz bilang "nama saya" } \\ F & : \text { Nama saya... } \\ \mathrm{P} & : \text { Siapa namanya? } \\ F & : \text { Bu Okti } \\ \mathrm{P} & : \text { Bukan, nama kamu siapa? } \\ F & : \text { Faiz } \\ \mathrm{P} & : \text { Faiz, nama lengkapnya? } \\ F & : \text { Bu Okti } \\ \mathrm{P} & : \text { Bukan, nama kamu? } \\ F & : \text { Bu... Faiz }\end{array}$

Anak autis mengalami gangguan komunikasi terutama bahasa dari fonologi, prosodi, sintaksis, komprehensi, dan semantik. Apabila sampai usia 2 tahun anak masih belum dapat berbicara, maka prognosa umumnya buruk. Tetapi apabila sampai usia 5 tahun anak masih belum mampu bicara, maka kemungkinannya kecil untuk anak dapat berbicara. Selain itu, anak autis tidak memiliki variasi nada suara sehingga nada bicaranya datar dan kadang-kadang secara tiba-tiba nada suaranya menjadi tinggi. Ada pula anak autis yang bicara dengan nada tinggi ketika mengoceh (babbling) namun ketika berkomunikasi suaranya rendah.

Kelainan pada anak autis ditemukan pada otak kecil, yang berfungsi untuk melakukan proses daya ingat, berpikir, aktivitas sensoris, perhatian, dan belajar bahasa. Kemampuan komunikasi fungsional yang dimiliki sangat terbatas sehingga miskin ide bicara bahkan terkadang ada kata-kata yang ditukar, misalnya antara kata "saya" dan "kamu". Sering kali mengalami gangguan interpretasi bahasa, misalnya "kaki gunung" akan diartikan sebagai "gunung berkaki". Contoh lain "ikan kumis" akan diartikan sebagai "ikan yang memiliki kumis".

Pada umumnya, anak autis yang mampu berbicara tidak memiliki masalah yang berat dalam perkembangan fonologi dan sintaksis serta mampu membuat gramatika yang benar. Namun, pembicaraan tersebut tidak memiliki arti dan tidak mudah dipahami orang lain. Anak autis sering kali mengalami gangguan dalam pembentukan kata dalam kalimat terutama dalam bidang sintaksis. Kesalahan-kesalahan tersebut bisa terjadi pada tataran struktur sintaksis atau kesalahan gramatikal dalam menerapkan fungsi-fungsi sintaksis. Penempatan yang salah dari kata benda dan kata kerja serta penggunaan kata kerja transitif tanpa objek disebut cacat sintaksis. Secara umum, pemproduksian bahasa atau sintaksis 
anak autis hanya berupa rangkaian-rangkaian frasa saja. Namun ada juga sebagian yang telah mampu memproduksi frasa, klausa, dan kalimat.

Studi neurolinguistik digunakan untuk memahami kerja otak untuk proses kegiatan berbahasa. Neurolinguistik lebih berkecimpung dalam memahami kesulitan berbahasa atau gangguan berbahasa, yang mencakup kegiatan bicara, mendengar, membaca, menulis, dan berbahasa isyarat yang mengganggu kemampuan berkomunikasi. Kajian neurolinguistik dapat digunakan untuk mengetahui bagaimana kaitan cacat bahasa terutama cacat sintaksis dengan gangguan fungsi otak dalam kegiatan berbahasa. Ada pun tujuan penelitian ini untuk mengetahui cacat sintaksis anak autis. Untuk mendapatkan data secara teliti dan tepat, peneliti hanya memfokuskan pada cacat sintaksis yang dialami oleh anak autis.

\section{METODE PENELITIAN}

Tujuan penelitian ini adalah untuk mengetahui cacat sintaksis anak autis. Selain itu, penelitian ini bertujuan untuk mengetahui kemampuan anak autis dalam memproduksi kata, frasa, klausa, dan kalimat. Metode penelitian yang digunakan dalam penelitian ini adalah metode deskriptif kualitatif dengan teknik deskripsi analisis isi. Penelitian ini dilaksanakan pada semester genap bulan Februari-Mei tahun akademik 2013/2014 dengan pengambilan data di SD Lab. PGSD, Setia Budi dan SDIT Al-Mubarak, Jakarta. Penelitian ini difokuskan pada cacat sintaksis yang dialami oleh anak autis sebanyak 4 orang di SD Lab. PGSD, Setia Budi dan SDIT Al-Mubarak, Jakarta. Objek penelitian yang akan diteliti pada penelitian ini adalah keluaran wicara anak autis. Jumlah informan yang diteliti dalam penelitian ini sebanyak 4 orang.

\section{HASIL DAN PEMBAHASAN}

Autisme merupakan kelainan yang disebabkan adanya gangguan neurobiologis pada susunan saraf pusat (otak). Gangguan ini termasuk dalam gangguan tumbuh kembang berupa sekumpulan gejala akibat adanya kelainan saraf-saraf tertentu yang menyebabkan fungsi otak tidak bekerja secara normal sehingga mempengaruhi tumbuh kembang, kemampuan berkomunikasi, dan kemampuan interaksi sosial seseorang.

Cacat sintaksis meliputi penempatan yang salah dari kata benda dan kata kerja, serta penggunaan kata kerja transitif tanpa objek. Kesalahan dalam sintaksis dianggap sebagai bagian dari kelainan dalam bahasa jika berlanjut pada usia yang seharusnya kebiasaan ini sudah hilang. Urutan, bentuk kata, intonasi, dan partikel atau kata tugas adalah alat-alat sintaksis. Secara umum struktur sintaksis terdiri dari susunan subjek (S), predikat $(\mathrm{P})$, objek $(\mathrm{O})$, dan keterangan $(\mathrm{K})$. Satuan sintaksis berupa kata, frasa, klausa, dan kalimat. Dalam satuan sintaksis terdapat fungsi-fungsi sintaksis yang terdiri dari unsurunsur S, P, O, K yang merupakan "kotak-kotak kosong" atau "tempat-tempat kosong" yang akan diisi oleh sesuatu yang berupa kategori dan memiliki peran tertentu.

Dalam data terdapat 67 kalimat ujaran dalam satu konteks komunikasi. dari ujaran empat anak autis ditemukan sebanyak 67 kalimat ujaran ditemukan sebanyak 17 kesalahan urutan kata, 1 kesalahan bentuk kata, tidak ditemukan kesalahan intonasi, 1 kesalahan kata tugas, dan kesalahan satuan sintaksis sebanyak 11 kesalahan frasa, 4 kesalahan klausa, dan tidak ditemukan kesalahan kalimat.

Berikut contoh temuan cacat sintaksis dalam penelitian ini.

\section{Data I :}

P : Coba lihat gambar ini. Ini lagi di mana?

$F$ : Memancing.

$\mathrm{P}$ : Memancing di mana? 
Arkhais, Vol. 06 No. 1 Januari-Juni 2015

F : Memancing.

$\mathrm{P}:$ Ini siapa?

F : Memancing Faiz.

Analisis :

Faiz bisa menjawab dengan benar meski kesulitan dalam menentukan kata. Dia menyebutkan pelaku yang di gambar adalah dirinya. Ujaran "memancing Faiz" mengalami ketidaksesuaian dalam fungsi sintaksis yang seharusnya "Faiz memancing." Hal ini disebabkan karena kesulitan dalam fungsi sensoris dan proses urutan.

Data II :

GP : Ini gambar apa? Lihat gambar apa

C : Badai. Kual acap. Pousi udala (Bajaj. Keluar asap. Polusi udara)

GP : Dari mana keluar asap?

$C$ : Kual api acap (keluar api asap)

Analisis :

Terdapat cacat pelafalan konsonan [j], [r], [s], dan penghilangan konsonan [1], [e] serta penambahan pada frasa "Badai. Kual acap. Pousi udala." Ujaran yang dihasilkan Fadzly terjadi ketidakberaturan pada proses urutan kata. Hal ini disebabkan adanya gangguan neurobiologis pada susunan saraf pusat (otak).

Cacat alat sintaksis terdiri dari 89,47\% kesalahan urutan kata; 5,26\% kesalahan bentuk kata; $0 \%$ tidak ada dalam intonasi; 5,26\% kesalahan kata tugas. Cacat satuan sintaksis terdiri dari 73,33\% kesalahan frasa; 26,67\% kesalahan klausa; dan 0\% tidak ada pada tataran kalimat. Dari keseluruhancacat alat sintaksis dan cacat satuan sintaksis, diperoleh paling banyak cacat alat sintaksis urutan kata sebesar $89.47 \%$ dan cacat satuan sintaksis frasa sebesar $73.33 \%$.

Kesalahan dalam fungsi sintaksis paling sedikit. Kesalahan alat sintaksis terbanyak ada pada urutan kata berupa kata-kata yang belum bisa membentuk fungsi sintaksis secara utuh. Kesalahan bentuk kata berupa kesalahan afiks namun jarang ditemukan karena ujaran yang dihasilkan hanya berupa kata. Kesalahan intonasi tidak ditemukan karena ujaran belum sempurna dan hanya berupa satu kata. Kesalahan partikel atau kata tugas ditemukan satu buah.

Kesalahan satuan sintaksis berupa frasa terjadi karena bentuk urutan yang salah sehingga berpengaruh pada produksi frasa anak autis. Kesalahan tersebut terjadi pada fungsi sintaksis keterangan waktu. Frasa yang sering diujarkan adalah frasa nomina dan frasa verba. Kesalahan satuan sintaksis klausa berupa kesalahan antara subjek dan predikat. Kalimat yang dihasilkan oleh anak autis berupa kalimat minor seperti salam dan ucapan terima kasih.

\section{KESIMPULAN}

Berdasarkan hasil analisis, interpretasi, dan pembahasan, maka dapat diketahui bahwa cacat alat sintaksis berupa kesalahan urutan kata paling banyak ditemui dan cacat satuan sintaksis berupa kesalahan frasa juga paling banyak ditemui. Kebanyakan gangguan berbahasa yang muncul adalah echolalia berupa pengulangan kata, seperti meniru kata atau kalimat secara berulang. Anak autis memiliki kecenderungan akan menjawab dengan mengulang kata yang terakhir dari kalimat pertanyaan dan hanya mampu memproduksi 
Arkhais, Vol. 06 No. 1 Januari-Juni 2015

satu kata dalam satu fungsi sintaksis. Ujaran berupa frasa berfungsi untuk mengekspresikan respon dari pertanyaan. Bagi anak autis, kata yang diujarkan sebenarnya kalimat penuh, tetapi karena dia belum dapat mengatakan lebih dari satu kata, dia hanya mengambil satu kata dari seluruh kalimat itu. Misalnya kata "rusak" ketika dia melihat jam, dapat berupa "jam itu rusak." Anak autis tidak dapat langsung menyebutkan jumlah benda yang dilihat. Ujaran yang keluar berupa kata "satu, dua, tiga, empat". Contoh lain ketika melihat sebuah tanda panah ke arah kanan, anak autis perlu ditanya berulang kali sehingga menghasilkan produksi yang lengkap.

\section{DAFTAR RUJUKAN}

Achmad HP. 2012. Sintaksis Bahasa Indonesia. Tanggerang: PT Pustaka Mandiri.

Achmad HP dan Alek Abdullah. 2012. Linguistik Umum. Jakarta: Penerbit Erlangga. Chaer, Abdul. 2007. Linguistik Umum. Jakarta: Rineka Cipta.

Dardjowidjojo, Soejono. 2008. Psikolinguistik Pengantar Pemahaman BahasaManusia. Jakarta: Yayasan Obor Indonesia.

Hidajati, Zuhriah. 2009. Dalam tesis yang berjudul Faktor Risiko DisfasiaPerkembangan pada Anak. Universitas Diponegoro: Semarang.

Huzaemah. 2010. Kenali Autisme Sejak Dini. Jakarta: Pustaka Populer Obor. Zaenal dan Junaiyah. 2008. Sintaksis. Jakarta: Grasindo.

Kaswanti Purwo, Bambang. 1985. Ancangan Psikolinguistik dan Pengajaran BahasaPertama. Jakarta: Arcan.

Kridalaksana, Harimurti. 2008. Kamus Linguistik Edisi Keempat. Jakarta: Penerbit Gramedia Pustaka Utama.

Kusmana, Ade. Perilaku Bahasa Menyimpang pada Peserta Didik, Jambi: Universitas Jambi.

MS, Mahsun. 2007. Metode Penelitian Bahasa Tahapan Strategi Metode danTekniknya. Jakarta: PT Raja Grafindo Persada.

Ramlan. 1986. Sintaksis. Yogyakarta: CV Karyono.

Sidarto, Lily. 1991. Berbagai Gangguan Berbahasa pada Anak dalam jurnal PELLBA 4 Linguistik Neurologi. Yogyakarta: Kanisius.

Sunu, Christopher. 2012. Panduan Memecahkan Masalah Autisme Unlocking Autism. Yogyakarta: Penerbit Lintangterbit.

Sugono, Dendy. 2012. Pembelajaran Bahasa Pascagangguan Otak. Jakarta.

Tisnasari, Sundawati. 2009. Ekspresi Pemahaman Anak Autis: Suatu AnalisisNeurolinguistik (Kasus Subjek Tunggal). Dalam MLI Kongres 
Arkhais, Vol. 06 No. 1 Januari-Juni 2015

InternasionalMasyarakat Linguistik Indonesia (KIMLI), Universitas Negeri Malang, halaman 314-317.

Setiadi, Hedi. 2012. Analisis Pemerolehan Struktur Sintaksis Anak Autis SDN PuteracoIndah Bandung. Dalam KOLITA 10, Universitas Katolik Indonesia Atma Jaya,halaman 41-45.

Verhaar, J.W.M. 2010. Asas-Asas Linguistik Umum. Yogyakarta: Gadjah Mada University Press.

Williams, Chris dan Barry Wright. 2004. How to Live with Autism and AspergerSyndrome. Jakarta: Dian Rakyat.

Yatim, Faisal. 2007. Autisme. Suatu Gangguan Jiwa pada Anak-Anak. Jakarta: Pustaka Populer Obor.

Yeanny Ekawati dan Yustina Yettie. Perkembangan Interaksi Sosial Anak Autis diSekolah Inklusi: Ditinjau dari Perspektif Ibu. Surabaya: Universitas KatolikWidya Mandala Surabaya. 